\title{
Comparative Evaluation of Stress Distribution around Various Threaded Implants with and without Platform Switch: A 3-D Finite Element Analysis
}

\author{
Gulshan K Tomar ${ }^{1}$, Mirna Garhnayak ${ }^{2}$, Abhijita Mahapatra ${ }^{3}$, Sitansu S Das ${ }^{4}$, Abhilash Mohapatra ${ }^{5}$, Gopal K Choudhury ${ }^{6}$
}

\begin{abstract}
Aim: The purpose of this study was to compare the stress distribution around various thread design implants with or without platform switching in the maxillary posterior region.

Materials and methods: Stress-based performances of four different thread design implants (single, double, triple, and asymmetric thread design each with or without platform switching) were analyzed by the three-dimensional finite element method under a static load of $100 \mathrm{~N}$ at $15^{\circ}$ oblique direction buccolingually at the central portion of the abutment. A geometric model of the posterior maxillary segment (first molar region) with an implant and abutment was modeled using the CATIA V5R19 software. Type IV bone quality was approximated and complete osseous integration was assumed.

Results: The von Mises stresses recorded around the neck of the fourthread design implants without platform switching were greater than the platform switching variety. The single-threaded implant with platform switching showed the lowest amount of von Mises stress. Additionally, total displacement or micromovement of single, triple, and asymmetric thread implants with platform switching was found to be greater than the without platform switching variety. Further, the total displacement of the single-threaded implant without platform switching was lowest. Conclusion: Implant surface design, platform switching, and site of placement affect load transmission mechanisms. Due to low crestal resorption, single thread design with platform switching is preferred. The success of an implant in the maxillary molar region is more challenging in terms of the density of bone and the worst load transfer mechanism. With the right kind of implant surface design selection, this can be reduced to a great extent by the preservation of crest of the ridge.

Clinical significance: Crestal bone resorption following implant placement is an important issue. An optimum implant design with a single thread having a platform switch could compensate for this issue to a great extent.

Keywords: Finite element analysis, Platform switching, Threaded implant.

The Journal of Contemporary Dental Practice (2020): 10.5005/jp-journals-10024-2895
\end{abstract}

\section{INTRODUCTION}

The continuous research in the field of dental implants has made them survivable and predictable. ${ }^{1-4}$ It can be attributed to modifications in implant design, materials, and surgical techniques. ${ }^{5}$ The incidence of dental implant failures is still a concern, particularly in the maxillary posterior region. ${ }^{1,6-15}$ Osseointegration failure in this region can be ascribed to poor oral health along with biomechanical factors like dental implant and quality of surrounding bone.,16-23 Implant design favoring optimum dissipation force at the implantbone junction is essential to make them predictable in the maxillary posterior region.

The thread of the implant is an important biomechanical factor that maximizes initial contact, improve initial stability, enlarge implant surface area, and favor dissipation of interfacial stress. $^{24,25}$ Based on thread helix, single-thread, double-thread, triple-thread, and asymmetric thread type implants are available commercially. ${ }^{26,27}$ The double- and triple-threaded implants are presumed to thread faster into the osteotomy site and are primarily indicated in type IV cancellous bone. ${ }^{26,27}$ Asymmetric implants with micro threads in the coronal portion of the implant have been claimed to reduce marginal bone loss, maintain peri-implant soft tissues and increase the bone implant contact (BIC). ${ }^{25,28-30}$ However some studies defy this. ${ }^{31}$

Crestal bone loss due to high stress and strain in cortical bone, are further reduced when a narrow-diameter abutment with a wider-shift implant collar is used-a concept called platform

\begin{abstract}
${ }^{1-6}$ Department of Prosthodontics, Institute of Dental Sciences, Siksha 'O' Anusandhan (Deemed to be University), Bhubaneswar, Odisha, India

Corresponding Author: Mirna Garhnayak, Department of Prosthodontics, Institute of Dental Sciences, Siksha 'O' Anusandhan (Deemed to be University), Bhubaneswar, Odisha, India, Phone: +91 8457011217; e-mail: mirnagarhnayak@gmail.com

How to cite this article: Tomar GK, Garhnayak M, Mahapatra A, et al. Comparative Evaluation of Stress Distribution around Various Threaded Implants with and without Platform Switch: A 3-D Finite Element Analysis. J Contemp Dent Pract 2020;21(8):891-896.

Source of support: Nil

Conflict of interest: None
\end{abstract}

switching. ${ }^{32-34}$ This relocates the implant-abutment junction toward the central axis. ${ }^{35}$ So stress distribution shifts from compact to the spongy bone under oblique load. ${ }^{36}$ The hemogeneous distribution of force along the length of the implant decreases the mean crestal bone loss to around $0.22 \mathrm{~mm} .^{37,38}$

Apart from implant design, bone quality has a vital role to play in the success of implant therapy. ${ }^{39}$ The literature suggests that only 3\% of Brånemark System implants (Nobel Biocare, Göteborg, Sweden) placed in type I, II, and III bone were lost after 5 years, while in type IV bone, failure rates were $35 \%$ over the same period. ${ }^{40}$ This can be attributed to the small implant-to-bone contact area and 
the inferior bone quality. ${ }^{41}$ The posterior region of the maxilla is mostly made up of type IV bone. ${ }^{32,42,43}$ So implant design favoring optimum dissipation of force along the implant-abutment interface is required in this region for clinical success. ${ }^{44-47}$

The stress analysis of implant-bone mechanical interactions, around various thread design (single, double, triple, and asymmetric threaded) implants with or without platform switching, in the maxillary posterior region, can suggest the ideal implant design. ${ }^{48,49}$ This is better done with the finite element analysis (FEA), owing to the complex geometry of the bone-implant biomechanical system. ${ }^{50,51}$ The FEA is a numerical tool that analyzes very complex and irregular structures. It breaks the complex structures into many small simple interrelated blocks or elements using a mathematical technique. Hence, the stress and deflection of all parts of the structure are calculated precisely. ${ }^{52,53}$

The purpose of this three-dimensional (3-D) FEA study was to assess and compare the effect of various thread design (single, double, triple, and asymmetric threaded) implants with or without platform switching on stress on cortical bone and overall displacement of the implant-abutment complex in the maxillary posterior region. This will help in the selection of a proper design implant for the maxillary posterior region.

\section{Materials and Methods}

This observational descriptive research using a 3-D FEA was conducted in the Department of Prosthodontics, Institute of Dental Sciences and ITER, SOAU, Bhubaneswar, Odisha. For this study, eight 3-D geometric models were generated using the CATIA V5R19 software. A computer with a 19 inch widescreen monitor, 8 GB RAM, Intel 5 (i5) processor along with memory capacity of 1 TB hard disk was used for the purpose. Each model comprised an implant, abutment, and bone block. For standardization, parameters of all the models were kept identical except for the implant thread design. Data for the models were adapted from the literature.

Four different thread design single-piece implants (single, double, triple, and asymmetric thread), each with and without platform switching ( $n=8$ ), were used for the purpose (Figs 1 to 4). Single-piece implants were preferred for their simple design and better dissipation of force along with the fixture. ${ }^{54}$ Short- and widediameter implants, each having $7 \mathrm{~mm}$ length and $5 \mathrm{~mm}$ diameter, were used..$^{55}$ The thread dimensions of implants used for the models are given in the tabular form (Table 1). ${ }^{56-59}$ All the abutments were having a height of $4 \mathrm{~mm}$ and 3-degree taper all around from the
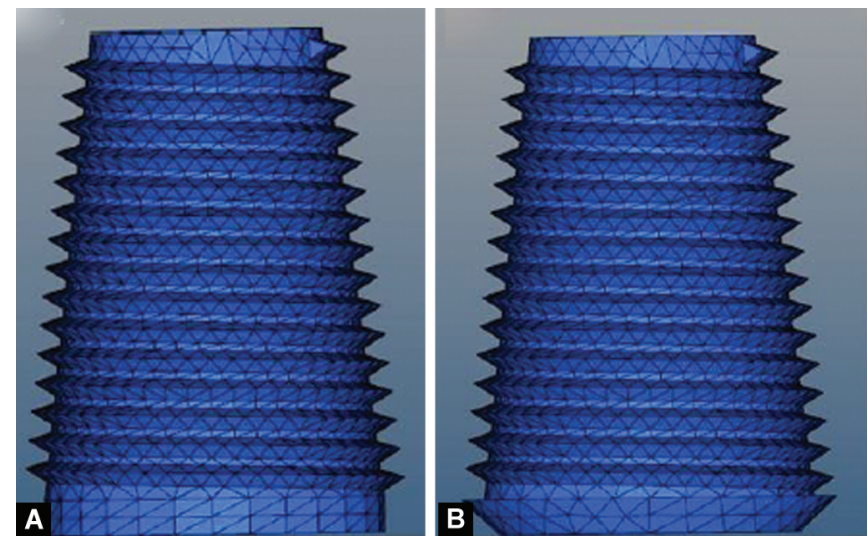

Figs $1 \mathrm{~A}$ and $\mathrm{B}$ : (A) Mesh form of single-thread implant design without platform switching; (B) Mesh form of single-thread implant design with platform switching vertical axis. ${ }^{56-59}$ Data for implant models were taken from the Nobel Biocare catalog.

A segment of D4 quality bone, resembling the missing maxillary first molar region, was considered for models. For simplification, bone geometry was simulated as two coaxial cylinders. The inner core was cancellous D4 bone, with a diameter of $14 \mathrm{~mm}$ and a height of $22 \mathrm{~mm} .{ }^{39}$ It was surrounded by an outer cylinder of 0.5 $\mathrm{mm}$ thickness representing the cortical bone, with a diameter of $15 \mathrm{~mm}$ and a height of $23 \mathrm{~mm}$. Data for all the models were based on the previous literature. ${ }^{60,61}$

Once 3-D geometric models were created with CATIA V5R19 software (solidwork; Avions Marcel Dassault, France), they were exported to FEA software ANSYS (ANSYS 13.0, ANSYS Inc., Houston, TX, USA). Here, these models were meshed with Hypermesh v11.0 (ANSYS version 13 software), using 10-node tetrahedral elements, to generate the 3-D FEA models. Each node was assigned $4^{\circ}$ of freedom. Care was taken to ensure that meshes on adjacent patches are compatible so that no node was isolated. The modulus of elasticity and Poisson's ratio of each material were specified concerning their location in the finite element models. Elastic properties of various materials were adopted from the literature and the materials of all models were presumed to be isotropic, homogeneous, and linearly elastic (Table 2). ${ }^{62}$

In this study, the interface between the implant and bone in FEA models was assumed to be an immovable junction, indicating $100 \%$ osseointegration between the implant and the bone. ${ }^{54}$ This is also supported by Papavasiliou et al. who observed that different degrees of osseointegration do not affect the stress level or distribution of axial or oblique load. ${ }^{63}$ An oblique load of $100 \mathrm{~N}$ was applied in the buccopalatal direction, at the mid-center of the abutment of the one-piece implant system. It was at an angle of 15 degrees to the vertical. ${ }^{55}$ For loading, an oblique force was chosen, as it is more realistic during chewing and will result in localized stress in cortical bone. ${ }^{32}$

For 3-D FEA, descriptive statistics were computed to compare the results of von Mises stress distribution and total displacement between different thread design implants (single, double, triple, and asymmetric thread), each with and without platform switching.

\section{Results}

Stress generated in the cortical bone (von Mises equivalent stress - MPa), around the various thread design implants each with


Figs 2A and B: (A) Mesh form of double-thread implant design without platform switching; (B) Mesh form of double-thread implant design with platform switching 

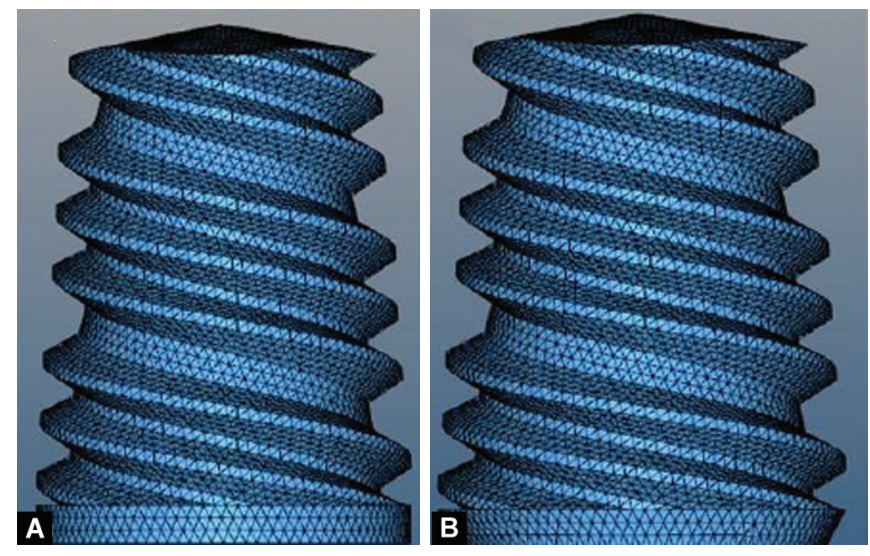

Figs $3 A$ and $B$ : (A) Mesh form of triple-thread implant design without platform switching; (B) Mesh form of triple-thread implant design with platform switching
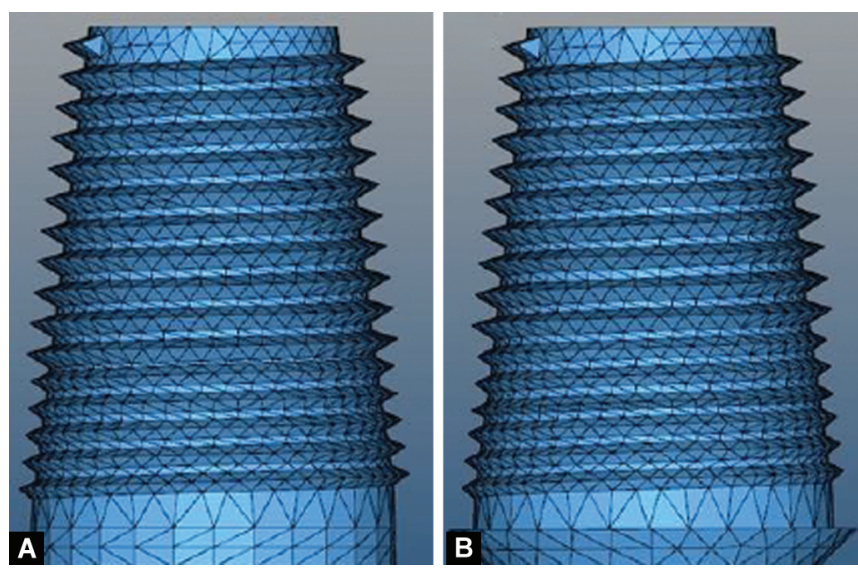

Figs 4A and B: (A) Mesh form of asymmetric thread implant design without platform switching; (B) Mesh form of asymmetric thread implant design with platform switching

Table 1: Thread dimensions of four implant designs

\begin{tabular}{|c|c|c|c|c|c|c|}
\hline \multicolumn{2}{|c|}{ Implant thread design } & Pitch $(\mathrm{mm})$ & $\begin{array}{l}\text { Thread depth with/without } \\
\text { platform switch }(\mathrm{mm})\end{array}$ & $\begin{array}{l}\text { Thread length } \\
(\mathrm{mm})\end{array}$ & Collar height (mm) & $\begin{array}{l}\text { Tip diameter of } \\
\text { implant }(\mathrm{mm})\end{array}$ \\
\hline \multicolumn{2}{|l|}{ Single } & 0.8 & 0.5 & 6.5 & 0.5 & 2.98 \\
\hline \multicolumn{2}{|l|}{ Double } & 1.6 & 0.5 & 6.5 & 0.5 & 2.98 \\
\hline \multicolumn{2}{|l|}{ Triple } & 2.4 & 0.5 & 6.5 & 0.5 & 2.98 \\
\hline \multirow[t]{2}{*}{ Asymmetric } & Coronal & 0.4 & 0.25 & 0.5 & 0.5 & 2.98 \\
\hline & Body portion & 0.8 & 0.5 & 0.5 & 0.5 & 2.98 \\
\hline
\end{tabular}

Table 2: Material properties ${ }^{62}$

\begin{tabular}{lll}
\hline Material & Young's modulus & Poisson's ratio \\
\hline Trabecular bone (D4) & $1.10 \mathrm{GPa}$ & 0.3 \\
Cortical bone & $13.7 \mathrm{GPa}$ & 0.3 \\
Titanium & $110.000 \mathrm{MPa}$ & 0.33 \\
\hline
\end{tabular}

Courtesy: Desai SR, Singh R, Karthikeyan I. 2D FEA of evaluation of micromovements and stresses at bone-implant interface in immediately loaded tapered implants in the posterior maxilla. J Indian Soc Periodontol 2013;17(5):637-643 (Reference no: 62)

or without platform switching, and the total displacement (micromovement) were computed using the ANSYS version 13 software program. Stress distribution in the FE model is normally expressed in numerical values corresponding to the particular color coding. Algebraic maximum and minimum values of von Mises stresses are denoted by red and blue colors, respectively. The intermediate values are represented in the form of bluish-green, green, greenishyellow, and yellowish red in the increasing order.

Stress distribution around the platform-switched, singlethreaded implant is expressed in the form of colored patterns as shown in the figure (Fig. 5). Similar stress patterns were also found for the double-thread, triple-thread, and asymmetric thread implants with and without platform switching. The stress values obtained for all the implant designs were tabulated and compared in the following manner (Tables 3 and 4).

\section{von Mises Stress (MPa) in the Cortical Bone around Various Thread Design Implants with or without Platform Switching}

Out of four different thread designs, maximum von Mises stress was produced by the double-threaded implant (19.9-21.6 MPa), whereas single-threaded implant produced minimum von Mises stress (15.4-16.2 MPa) in the cortical plate. Again, implants with platform switching exert less stress (15.4-19.9 MPa) in the cortical bone around the implant than without platform switching.

\section{Total Displacement (Micromovement) of Various Thread Design Implants with and without Platform Switching in the Bone}

In comparison to the double, triple, and asymmetric thread variety implants, minimum overall displacement was seen in a single-threaded implant with and without platform switching (0.011664-0.008524 mm). On the contrary, implants with platform switching showed more overall displacement (0.011664-0.013129 $\mathrm{mm}$ ) in the surrounding bone. ${ }^{31}$ After analyzing the results, it can be presumed that out of all different implant designs, a single-threaded implant favors better stress distribution and minimum stress to the cortical bone around the implant. It also has a minimum overall displacement among all different designs.

\section{Discussion}

In the present study, the 3-D FEA method is used to assess the effect of various thread design (single, double, triple, and asymmetric threaded) implants with or without platform switching on cortical bone stress and overall displacement of the implant-abutment complex in the maxillary posterior region.

Crestal bone loss is an important factor determining the longterm prognosis of the implant. This can be prevented when vertical bone loss around an implant is not exceeded by $2 \mathrm{~mm}$ for the first year and remain less than $0.2 \mathrm{~mm}$ annually. This will preserve the biologic width around the implant. ${ }^{64}$ The result of the study showed that maximum von Mises stress in the cortical plate was produced 


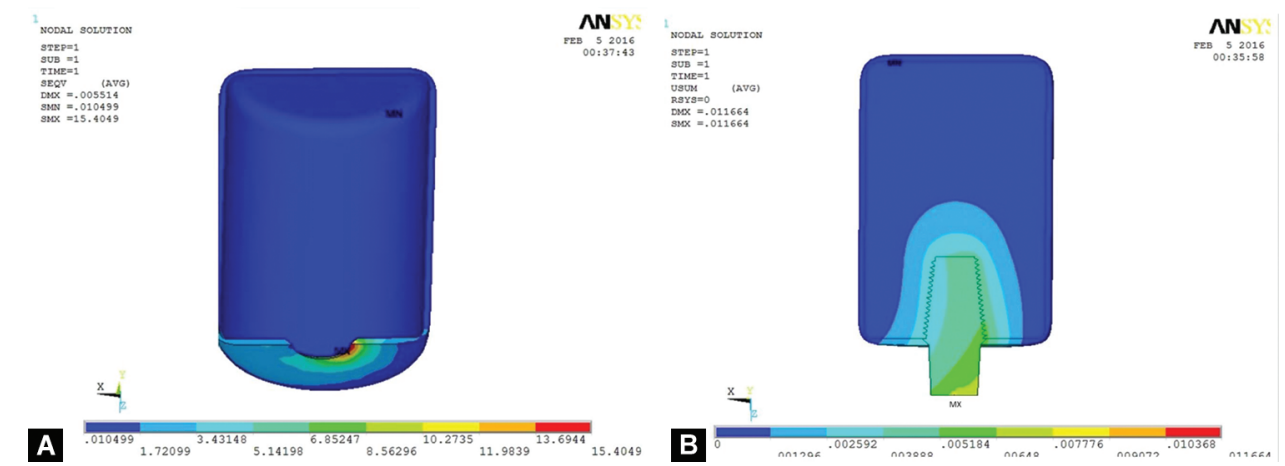

Figs 5A and B: (A) Von Mises stress on cortical plate with platform-switched single-threaded implant; (B) Total displacement (micromovement) with platform-switched single-threaded implant

Table 3: Comparison of cortical stress distribution between various thread design implants with and without platform switching by 3-D FEA

\begin{tabular}{|c|c|c|}
\hline \multicolumn{3}{|c|}{ von Mises stress on cortical bone (MPa) } \\
\hline $\begin{array}{l}\text { Thread design of } \\
\text { implant }\end{array}$ & Platform switched & Without platform \\
\hline Single threaded & 15.4 & 16.2 \\
\hline Double threaded & 19.9 & 21.6 \\
\hline Triple treaded & 19.7 & 21.0 \\
\hline Asymmetric threaded & 16 & 17 \\
\hline
\end{tabular}

Table 4: Comparison of total displacement between various thread design implants with and without platform switching by 3-D FEA

\begin{tabular}{lll}
\hline \multicolumn{2}{l}{ Total displacement $(\mathrm{mm})$} & \\
$\begin{array}{l}\text { Thread design of } \\
\text { implant }\end{array}$ & Platform switched & Without platform \\
\hline Single threaded & 0.011664 & 0.008524 \\
Double threaded & 0.011666 & 0.013129 \\
Triple treaded & 0.013129 & 0.012884 \\
Asymmetric threaded & 0.01171 & 0.008568 \\
\hline
\end{tabular}

by the double-threaded implant, whereas minimum stress was produced by the single-threaded implant variety. This finding is in agreement with the study by Sun et al., who stated that the best stress transmission is shown by a single-threaded implant in comparison to other thread patterns. ${ }^{26}$

Again, implants with platform switching exerted less stress in the cortical bone around the implant in comparison with the implant without platform switching. In this regard, it complemented the previous study by Ferraz et al., who stated that in contrast to the regular platform, the platform switching concept reduces the stress and strain for the cortical plate. ${ }^{31}$ On the contrary, higher stress was found in trabecular bone for the platform switch variety. ${ }^{31}$ Minimum overall displacement was also seen in a single-threaded implant for both platform switching and without platform switching varieties. After analyzing the results, it can be concluded that out of all threaded implant designs, the single-threaded implant with platform switching is the best design. It distributes the stress evenly with minimum force transmission to the cortical bone around the implant. Again, it has a minimum overall displacement among all different designs.

One of the limitations of this study is the use of a single-piece implant to overcome the complexity of implant internal design modeling in two-piece implants. Again, the geometry of the bone model was not only simplified but also assumed to be isotropic and homogeneous for the simulated structure. Despite similar strength of the bone block to that of the jaw bone, the strain patterns might vary with the bone geometry. This could also have created a small margin of errors in results. ${ }^{54}$ Further, the properties of leaving tissue in an actual biological system might not be isotropic and hemogeneous, which needs to be studied further. ${ }^{55}$ Although oblique loading has been suggested to symbolize a realistic occlusal load, chewing movement, specifically with dynamic loading simulations, needs to be considered in future investigations. ${ }^{50}$ Each individual has a unique biological condition in terms of bone quality, force distribution, and masticatory activity. So, the results of the study need to be further substantiated by randomized clinical trials for clinical application. ${ }^{64}$

\section{Conclusion}

Within the limitations of the 3-D FEA study, it can be concluded that implants can be successfully placed in the maxillary posterior region. Cortical stress concentration in D4 bone is more for the asymmetric implant in comparison to the single-threaded implant, whereas stresses are less in comparison to double- and triplethreaded designs. Again, implants with platform switching exert less stress in the cortical bone around the implant than without platform switching. A single-threaded implant with platform switching showed even distribution of stress and is the suitable design out of four different designs of implants for the maxillary posterior region.

\section{References}

1. Adell R, Lekholm U, Rockler B, et al. A 15-year study of osseointegrated implants in the treatment of the edentulous jaw. Int J Oral Surg 1981;10(6):387-416. DOI: 10.1016/S0300-9785(81)80077-4.

2. Weibrich G, Buch RS, Wegener J, et al. Five-year prospective follow-up report of the Astra tech standard dental implant in clinical treatment. Int J Oral Maxillofacial Implants 2001;16(4):557-562.

3. Goodacre CJ, Bernal G, Rungcharassaeng K, et al. Clinical complications with implants and implant prostheses. J Prosthet Dent 2003;90(2):121-132. DOI: 10.1016/S0022-3913(03)00212-9.

4. Fugazzotto PA. Success and failure rates of osseointegrated implants in function in regenerated bone for 72 to 133 months. Int J Oral Maxillofac Implants 2005;20(1):77-83.

5. Mich CE. Implant design considerations for the posterior regions of the mouth. Implant Dent 1999;8(4):376-386. DOI: 10.1097/00008505199904000-00008. 
6. Weyant R. Short-term clinical success of root-form titanium implant systems. J Evid Based Dent Pract 2003;3(3):127-130. DOI: 10.1016/ S1532-3382(03)00063-0.

7. Roos-Jansåker AM, Lindahl C, Renvert H, et al. Nine- to fourteen-year follow-up of implant treatment. Part I: implant loss and associations to various factors. J Clin Periodontol 2006;33(4):283-289. DOI: 10.1111/j.1600-051X.2006.00907.x.

8. Tonetti MS. Determination of the success and failure of root-form osseointegrated dental implants. Adv Dent Res 1999;13:173-180. DOI: 10.1177/08959374990130010801.

9. Romeo E, Chiapasco M, Ghisolfi M, et al. Long-term clinical effectiveness of oral implants in the treatment of partial edentulism. Seven-year life table analysis of a prospective study with ITI dental implants system used for single-tooth restorations. Clin Oral Implants Res 2002;13(2):133-143. DOI: 10.1034/j.1600-0501.2002.130203.x.

10. Ericsson I, Nilson $\mathrm{H}$, Lindh $\mathrm{T}$, et al. Immediate functional loading of Brånemark single tooth implants. An 18 months clinical pilot follow-up study. Clin Oral Implants Res 2000;11(1):26-33. DOI: 10.1034/j.1600-0501.2000.011001026.x.

11. Piattelli A, Scarano A, Piattelli M, et al. Microscopical aspects of failure in osseointegrated dental implants: a report of five cases. Biomaterials 1996;17(1):235-241. DOI: 10.1016/0142-9612(96)84944-1.

12. Jemt T, Chai J, Harnett J, et al. A 5-year prospective multicenter follow-up report on overdentures supported by osseointegrated implants. Int J Oral Maxillofac Implants 1996;11(3):291-298.

13. Eckert SE, Wollan PC. Retrospective review of 1170 endosseous implants placed in partially edentulous jaws. J Prosthet Dent 1998;79(4):415-421. DOI: 10.1016/S0022-3913(98)70155-6.

14. Lekholm U, Gunne J, Henry P, et al. Survival of the Brånemark implant in partially edentulous jaws: a 10-year prospective multicenter study. Int J Oral Maxillofac Implants 1999;14(5):639-645.

15. Drago CJ. Rates of osseointegration of dental implants with regard to anatomical location. J Prosthodont 1992;1(1):29-31. DOI: 10.1111/j.1532-849X.1992.tb00423.x.

16. Lindquist LW, Carlsson GE, Jemt T, et al. A prospective 15-year follow-up study of mandibular fixed prostheses supported by osseointegrated implants. Clinical results and marginal bone loss. Clin Oral Implants Res 1996;7(4):329-336. DOI: 10.1034/j.16000501.1996.070405.x.

17. Lindquist LW, Rockler B, Carlsson GE, et al. Bone resorption around fixtures in edentulous patients treated with mandibular fixed tissue-integrated prostheses. J Prosthet Dent 1988;59:59-63. DOI: 10.1016/0022-3913(88)90109-6.

18. Schou S, Holmstrup P, Hansen EH, et al. Plaque-induced marginal tissue reactions of osseointegrated oral implants: a review of the literature. Clin Oral Implants Res 1992;3(4):149-161. DOI: 10.1034/j.1600-0501.1992.030401.x.

19. Block MS, Gardiner D, Kent JN, et al. Hydroxyapatite-coated cylindrical implants in the posterior mandible: 10 -year observations. Int J Oral Maxillofac Implants 1996;11(5):626-633.

20. van Steenberghe D, Lekholm U, Bolender C, et al. Applicability of osseointegrated oral implants in the rehabilitation of partial edentulism: a prospective multicenter study on 558 fixtures. Int J Oral Maxillofac Implants 1990;5(3):272-281.

21. Quirynen M, Naert I, van Steenberghe D, et al. Fixture design and overload influence marginal bone loss and fixture success in the Brånemark system. Clin Oral Implants Res 1992;3(3):104-111. DOI: 10.1034/j.1600-0501.1992.030302.x.

22. Isidor F. Loss of osseointegration caused by occlusal load of oral implants. A clinical and radiographic study in monkeys. Clin Oral Implants Res 1996;7(2):143-152. DOI: 10.1034/j.16000501.1996.070208.x.

23. Tada S, Stegaroiu R, Kitamura E, et al. Influence of implant design and bone quality on stress/strain distribution in bone around implants: a 3-dimensional finite element analysis. Int J Oral Maxillofac Implants 2003;18(3):357-368.
24. Abuhussein H, Pagni G, Rebaudi A, et al. The effect of thread pattern implant osseointegration. Clin Oral Implants Res 2010;21(2):129-136. DOI: 10.1111/j.1600-0501.2009.01800.x.

25. Ausiello $P$, Franciosa $P$, Martorelli $M$, et al. Effects of thread features in osseo-integrated titanium implants using a statistics-based finite element method. Dent Mater 2012;28(8):919-927. DOI: 10.1016/ j.dental.2012.04.035.

26. Sun Y, Kong L, Liu B, et al. Comparative study of single-thread, doublethread, and triple-thread dental implant: a three-dimensional finite element analysis. World J Modell Simul 2007;3(4):310-314.

27. Sykaras N, lacopino AM, Marker VA, et al. Implant materials, designs, and surface topographies: their effect on osseointegration. A literature review. Int J Oral Maxillofac Implants 2000;15(5):675-690.

28. Meric G, Erkmen E, Kurt A, et al. Biomechanical evaluation of a fiberreinforced composite prosthesis supported by implants with and without a microthread collar design. J Dent Sci 2010;5(4):201-208. DOI: 10.1016/j.jds.2010.11.010.

29. Lee DW, Choi YS, Park KH, et al. Effect of microthread on the maintenance of marginal bone level: a 3-year prospective study. Clin Oral Implants Res 2007;18(4):465-470. DOI: 10.1111/j.16000501.2007.01302.x.

30. Abrahamsson I, Berglundh T. Tissue characteristics at microthreaded implants: an experimental study in dogs. Clin Implant Dent Relat Res 2006;8(3):107-113. DOI: 10.1111/j.1708-8208.2006.00016.x.

31. Ferraz CC, Anchieta RB, de Almeida EO, et al. Influence of microthreads and platform switching on stress distribution in bone using angled abutments. J Prosthodont Res 2012;56(4):256-263. DOI: 10.1016/j. jpor.2012.02.002.

32. Holmgren EP, Seckinger RJ, Kilgren LM, et al. Evaluating parameters of osseointegrated dental implants using finite element analysis: a two-dimensional comparative study examining the effects of implant diameter, implant shape, and load direction. J Oral Implantol 1998;24(2):80-88. DOI: 10.1563/1548-1336(1998)024<0080:EPOODI> 2.3.CO;2.

33. Palmer RM, Smith BJ, Palmer PJ, et al. A prospective study of Astra single tooth implants. Clin Oral Implants Res 1997;8(3):173-179. DOI: 10.1034/j.1600-0501.1997.080303.x.

34. Gardner DM. Platform switching as a means to achieving implant esthetics. NY State Dent J 2005;71(3):34-37.

35. López-Marí L, Calvo-Guirado JL, Martín-Castellote B, et al. Implant platform switching concept: an updated review. Med Oral Patol Oral Cir Bucal 2009;14(9):e450-e454.

36. Chang $\mathrm{CL}$, Chen $\mathrm{CS}, \mathrm{Hsu} \mathrm{ML}$, et al. Biomechanical effect of platform switching in implant dentistry: a three-dimensional finite element analysis. Int J Oral Maxillofac Implants 2010;25(2):295-304.

37. Canullo L, Pace F, Coelho $P$, et al. The influence of platform switching on the biomechanical aspects of the implant abutment system. A three-dimensional finite element study. Med Oral Patol Oral Cir Bucal 2011;16(6):e852-e856. DOI: 10.4317/medoral.17243.

38. Prasad DK, Shetty M, Bansal N, et al. Crestal bone preservation: a review of different approaches for successful implant therapy. Indian J Dent Res 2011;22(2):317-323. DOI: 10.4103/0970-9290.84311.

39. Lekholm U, Zarb GA. Patient selection and preparation. In: Branemark PI, Zarb GA, Albrektsson T, ed. Tissue integrated prostheses: osseointegration in clinical dentistry. Chicago: Quintessence Publishing Company; 1985. pp. 199-209.

40. Jaffin RA, Berman CL. The excessive loss of Branemark fixtures in type IV bone: a 5-year analysis. J Periodontol 1991;62(1):2-4. DOI: 10.1902/ jop.1991.62.1.2.

41. Kim SH, Kim SJ, Lee KW, et al. The effects of local factors on the survival of dental implants: a 19-year retrospective study. J Korean Acad Prosthodont 2010;48(1):28-40. DOI: 10.4047/jkap.2010.48.1.28.

42. Sato $Y$, Wadamoto $M$, Tsuga $K$, et al. The effectiveness of element downsizing on a three-dimensional finite element model of bone trabeculae in implant biomechanics. J Oral Rehabil 1999;26(4):288291. DOI: 10.1046/j.1365-2842.1999.00390.x. 
43. Ichikawa T, Kanitani H, Wigianto R, et al. Influence of bone quality on the stress distribution. An in vitro experiment. Clin Oral Implants Res 1997;8(1):8-22. DOI: 10.1111/j.1600-0501.1997.tb00003.x.

44. Siegele $D$, Soltesz $U$. Numerical investigations of the influence of implant shape on stress distribution in the jaw bone. Int J Oral Maxillofac Implants 1989;4(4):333-340.

45. Misch CE. Density of bone: effect on treatment plans, surgical approach, healing, and progressive bone loading. Int J Oral Implantol 1990;6(2):23-31.

46. Sahin S, Cehreli MC, Yalçin E, et al. The influence of functional forces on the biomechanics of implant-supported prostheses: a review. J Dent 2002;30(7-8):271-282. DOI: 10.1016/S0300-5712(02)00065-9.

47. Papavasiliou G, Kamposiora P, Bayne SC, et al. Three-dimensional finite element analysis of stress distribution around single tooth implants as a function of bony support, prosthesis type, and loading during function. J Prosthet Dent 1996;76(6):633-664. DOI: 10.1016/ S0022-3913(96)90442-4.

48. Natali AN, Pavan PG. Numerical approach to dental biomechanics. In: Natali AN, ed. Dental biomechanics. London: Taylor and Francis; 2003. pp. 211-239.

49. Natali AN, Pavan PG. A comparative analysis based on different strength criteria for evaluation of risk factor for dental implants. Comput Methods Biomech Biomed Engin 2002;5(2):127-133. DOI: 10.1080/10255840290032144.

50. Geng IP, Tan KB, Liu GR, et al. Application of finite element analysis in implant dentistry: a review of the literature. J Prosthet Dent 2001;85(6):585-598. DOI: 10.1067/mpr.2001.115251.

51. Van Staden RC, Guan H, Loo YC, et al. Application of the finite element method in dental implant research. Comput Methods Biomech Biomed Engin 2006;9(4):257-270. DOI: 10.1080/10255840600837074.

52. Assaf JH, Filho AM, Zanatta FB, et al. Short implants with single-unit restorations in posterior regions with reduced height: a retrospective study. Braz J Oral Sci 2010;9(4):493-497.

53. Pierrisnard L, Hure G, Barquins $M$, et al. Two dental implants designed for immediate loading: a finite element analysis. Int J Oral Maxillofac Implants 2002;17(3):353-362.

54. Koka P, Mohapatra A, Anandapandian PA, et al. The effect of implant design on the stress distribution in a three-unit implant-supported distal cantilever fixed partial denture: a three-dimensional finiteelement analysis. Indian J Dent Res 2012;23(2):129-134. DOI: 10.4103/0970-9290.100413.

55. Desai SR, Singh R, Karthikeyan I, et al. Three-dimensional finite element analysis of effect of prosthetic materials and short implant biomechanics on D4 bone under immediate loading. J Dent Implants 2012;2(1):2-8. DOI: 10.4103/0974-6781.96556.

56. Li T, Kong L, Wang $Y$, et al. Selection of optimal dental implant diameter and length in type IV bone: a three-dimensional finite element analysis. Int J Oral Maxillofac Surg 2009;38(10):1077-1083. DOI: 10.1016/j.ijom.2009.07.001.

57. Kang YI, Lee DW, Park KH, et al. Effect of thread size on the implant neck area: preliminary results at 1 year of function. Clin Oral Implants Res 2012;23(10):1147-1151. DOI: 10.1111/j.1600-0501.2011.02298.x.

58. Ryu HS, Namgung C, Lee JH, et al. The influence of thread geometry on implant osseointegration under immediate loading: a literature review. J Adv Prosthodont 2014;6(6):547-554. DOI: 10.4047/ jap.2014.6.6.547.

59. Herekar MG, Patil VN, Mulani SS, et al. The influence of thread geometry on biomechanical load transfer to bone: a finite element analysis comparing two implant thread designs. Dent Res J Isfahan 2014;11(4):489-494.

60. Cruz M. Tri-Dimensional Stress Analysis Around a Cuneiform Implant by the Finite Element Method. Campinas, Brazil: M.D Sci. Thesis (Dentistry), Camilo Castelo Branco University; 2001. p. 134.

61. Cruz M, Wassal T, Toledo EM, et al. Int J Oral Maxillofac Implants 2003;18(5):675-684.

62. Desai SR, Singh R, Karthikeyan I. 2D FEA of evaluation of micro movements and stresses at bone-implant interface in immediately loaded tapered implants in the posterior maxilla. J Indian Soc Periodontol 2013;17(5):637-643. DOI: 10.4103/0972-124X.119283.

63. Papavasiliou G, Kamposiora P, Bayne SC, et al. 3D-FEA of osseointegration percentages and patterns on implant-bone interfacial stresses. J Dent 1997;25(6):485-491. DOI: 10.1016/S03005712(96)00061-9.

64. Shetty M, Prasad K, Sangeetha UN, et al. Platform switching: a new era in implant dentistry. Int J Oral Implant Clin Res 2010;1(2):61-65. DOI: 10.5005/jp-journals-10012-1010. 